\title{
Evaluating the Impact of Contingent Crop (Niger) on Rice Fellow Upland under Rainfed Ecosystem of Jharkhand, India
}

\author{
Chanchila Kumari $^{{ }^{*}}$, Binit Kumar ${ }^{1}$, Manish Kumar ${ }^{1}$ and V.K. Singh ${ }^{2}$ \\ ${ }^{1}$ Krishi Vigyan Kendra, Koderma, ICAR-NRRI-CRURRS, (Jharkhand), 825109 \\ ${ }^{2}$ Senior Scientist, IISR, Lucknow (Uttar Pradesh), 226002, India \\ *Corresponding author
}

\section{A B S T R A C T}

The evaluation of contingent crop (Niger) has been placed in two different locality of Koderma (Jharkhand). The two locations for inception of trail were selected on the basis of

\section{Keywords}

Rice, Contingent crop, Upland, Jharkhand

Article Info

Accepted:

20 April 2018

Available Online:

10 May 2018 failure of primary Kharif season crop rice on upland field condition. Aberrant and harsh weather condition including erratic, sometime lack to rainfall forced the farmers to transplant aged seeding which may directly affect the yield of rice. In the year of 2016-17 the Basdih and Paharpur village of Markacho block were selected for placement of Niger crop. The annual rainfall of Koderma region has been depicted by $200-250 \mathrm{~mm}$, because of unavailability of irrigation water total 35 hectare (Basdih village 20 hectare and Paharpur 15 hectare) of rice cultivated land have been failed to grow. So short duration, drought tolerant variety of Niger (JNC-6) has been sown. After collection of field data the results shows that the yield of niger on upland area recorded 3.5 quintal per hectare (net worth income 22, 072 INR), besides the yield on medium land observed up to 4.6 quintal per hectare (net worth income 22, 934 INR). This study shows land uses change in failure of primary crop with the application of contingent crop, the focus of study was based on aware the farmers about continuous change in environmental condition and selection of technology, varieties and showing methodology according to current climatic scenario.

\section{Introduction}

Not only cereal and pulse crop under food crops, oilseed crops are also equally important for the Indian agricultural economy. India ranks third in the world after China and USA in the production of oilseeds (Calskan et al., 2002). The oil seed crops have a wide adaptability and are grown under varied agroclimatic conditions throughout the world. The annual oilseed crops grown in India are soybean, groundnut, rape and mustard, linseed, sunflower, sesame, safflower and niger. The oil seeds, products and oil produced by the oilseed crops are important for cooking, preparation of pickles, flavoring the curry, animal feed, soap manufacture, industrial use, etc. (Chavan et al., 1998). Oil seeds have a very significant role in Indian agriculture since almost each part of the plant is consumed either by human beings or animal depending upon the crop and in growth stage. But the 
production and productivity of oil seeds is limited by a number of biotic and abiotic stresses (Hegde, 2012). Among the abiotic factors, temperature, rainfall, relative humidity, photoperiod and soil moisture are the limiting factors in realization of maximum yield (Damavandi et al., 2005). Climatic condition is the most variable factor in upland rainfed crop system in which cropping pattern, timing, intensity and area cover under cropping system totally depend upon availability of rainfall and other irrigation facilities. An unavoidable and irrespective change in climate is the one which cannot be controlled by human. Nearly $86 \%$ of agriculture practices in kharif season in Jharkhand is depend upon rainfall and the maximum part this forcibly faced the challenge of unavailability of rainfall during south west monsoon. Unfortunately aberrant weather is a common feature in Jharkhand state agriculture from last one decade (minimum rainfall received $860 \mathrm{~mm}$ during kharif season whereas the normal rainfall recorded up to $1050 \mathrm{~mm}$ annually, data collected from state agriculture department, Koderma, Jharkhand). The rainfall is seasonal, erratic and highly variable with space and time. The aberrant nature of rainfall may be due to early or delayed onset of monsoon ( $<$ 10-12 days) and withdrawal or associated drought spells (<10 days) at any stage of crop. The state of Jharkhand sole depends on mono cropping pattern with rice cultivation which is directly associated with rainfall and harvested water in natural or constructed water bodies. Niger (Guizotia abyssinica Cass.) is one of the important minor oilseed crops of India. It is considered as minor oil seed crop but it is very important in terms of its oil content, quality and potentiality. The important feature of this crop is that it gives reasonable seed yield even under poor marginal growing conditions. Niger is mainly used for extraction (about 30$50 \%$ ) of oil (Gaurilow et al., 2003). Oil is inferior quality and is used for soap making, lighting, lubrication and as drying oil. Whereas, plant is used for fodder and for making silage. It is mainly cultivated to a limited extent in India, it is chiefly cultivated in Madhya Pradesh, Orissa, Maharastra, Bihar, Karnataka and Andhra Pradesh mostly on the hill tops and slopes as a inter or mixed crop (Hafeez et al., 2001).

\section{Materials and Methods}

The crop inception was placed to study the impact of Niger (Guizotia abyssinica Cass.) on rice failed field on two different locality of Koderma Jharkhand for seed yield and quality during 2016-17. The Cultivar JNC-6 has been used for cultivation and the reploughing of rice field was done with country plough. The Basdih village field latitude is N24.365919, longitude E85.746940 and Paharpur village latitude N24.760846. The experimental site has a red soil, sandy loam and gravel soil. The climatic condition is drought, heat wave, cold wave and hailstorm. Before plantation of contingent crop following important factors might be keep in priority (Matinfer et al., 2011):

Select efficient crops and cropping systems matching the length of growing season. Some of the promising non-rice crops for rainfed uplands are maize, cowpea, Pigeon pea, Chick pea, and Niger.

Choose short duration varieties which possess faster rate of growth, deep and penetrating root system and ability to escape drought.

Store rain water to use as life saving irrigation. Perform off season ploughing to conserve moisture, reduce pest and weed problem and to facilitate early sowing. Two to three Plough and sowing the crops across the slope to develop a ridge and furrow type of land configuration for effective soil moisture conservation to overcome 
drought for longer period.

Follow partial mechanization to ensure timeliness and precise of operations (desired depth and tilth) to utilize land, rainfall and other natural resources effectively.

\section{Results and Discussion}

In the year of 2016-17 during Kharif season aberrant nature of rainfall (deviation\% 45.44) bounded farmers to transplant aged seeding $(<$ 30 days) in main field moreover approximately fifteen hectare of upland and medium area were uncultivated due to insufficient availability of irrigation. According the available research data due to transplanting of aged seeding and lack of irrigation it may reduced the grain yield which was directly affect the economic condition of farmers. To minimize the losses of farmers the contingent crop Niger i.e. drought resistant, high yielding variety JNC-6 (Jackson, 1967) was demonstrated on combinedly forty hectare of upland and medium land in Basdih and Paharpur village of Markacho Block. Contingency planning refers to mitigate any unexpected, unusual, unfavorable and unwanted accidental weather situations occurring at any time without prior knowledge at any time before the crops are sown or even after the crops are sown (Jadhav and Deshmukh, 2008) (Fig. A-E).

Table.1 Appearance of seasonal rainfall during monsoon Kharif 2016-17

\begin{tabular}{|l|l|c|l|c|}
\hline Rainfall summary for month & $\begin{array}{l}\text { Actual } \\
(\mathbf{m m})\end{array}$ & $\begin{array}{l}\text { Normal } \\
(\mathbf{m m})\end{array}$ & $\begin{array}{l}\text { Deviation } \\
\text { (Actual minus } \\
\text { Normal) }(\mathbf{m m})\end{array}$ & $\begin{array}{l}\text { Deviation (\%) } \\
\text { (Actual - Normal) x } \\
100 \\
\text { Normal }\end{array}$ \\
\hline June & 60.66 & 165.7 & 146.7 & $88.53 \%$ \\
\hline July & 470.8 & 323.7 & 147.1 & $45.44 \%$ \\
\hline August & 322.9 & 160.8 & 162.1 & $50.20 \%$ \\
\hline September & 101.8 & 214.3 & 112.5 & $52.49 \%$ \\
\hline October & 46.4 & 64.6 & 18.2 & $28.17 \%$ \\
\hline $\begin{array}{l}\text { Details of dry spells } \\
\text { experienced }\end{array}$ & 1) From: 03.09 .17 To: 15.09 .17 .2 2) From: 03.10.17 To: 31.10 .17 \\
\hline
\end{tabular}

Table.2 Economic study of placement of contingent crop on rice failed crop

\begin{tabular}{|c|c|c|c|c|c|c|}
\hline S.No & $\begin{array}{c}\text { Area of } \\
\text { demonstration }\end{array}$ & $\begin{array}{c}\text { Area } \\
\text { (Ha) }\end{array}$ & Yield (q/Ha) & $\begin{array}{c}\text { Gross } \\
\text { input }\end{array}$ & $\begin{array}{c}\text { Gross } \\
\text { return }\end{array}$ & $\begin{array}{c}\text { Net } \\
\text { return }\end{array}$ \\
\hline $\mathbf{1}$ & Upland rainfed & 35 & 3.5 & 13,560 & 35,632 & 22,072 \\
\hline $\mathbf{2}$ & Medium land & 5 & 4.6 & 15,590 & 38,524 & 22,934 \\
\hline
\end{tabular}


Fig.A Rice growing failed upland field; Fig.B Ploughing of field; Fig.C Sowing of Niger seed through ZTSD; Fig.D Germination of Niger Seed; Fig.E Typical growth of Niger
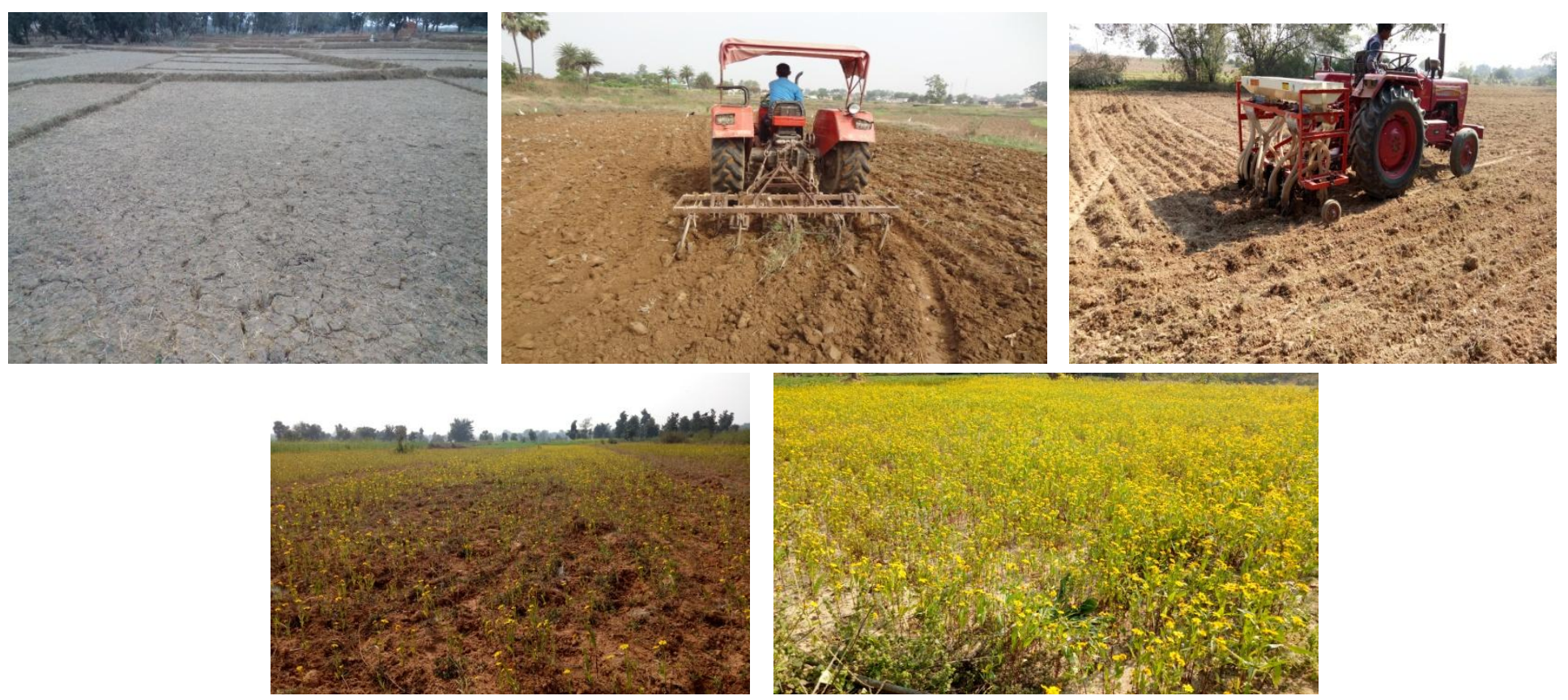

The contingency crop planning therefore is proposed to mitigate such situations through the choice of appropriate crops and varieties, cropping systems or other necessary relevant farm practice1s (Table 1 and 2). Timely formulation and implementation of contingent agricultural plans helps to mitigate the adverse effects of scanty rainfall on production and productivity of crops (Jagtap et al., 2015). Use of resource-conservation technologies (Zero Tillage Seed Drill Cum Fertilizer machine and Direct Seeded Rice) and a shift from sole cropping to diversify farming system is highly warranted (Madhu Bala and Kedar Nath, 2015). The success of contingent cropping system shows that the suitable crop compatibility, production potential and economics during failure of main crop.

\section{References}

Jackson, M. L. (1967) Soil chemical analysis. Prentice hall of India Pvt., New Delhi Pp. 498.

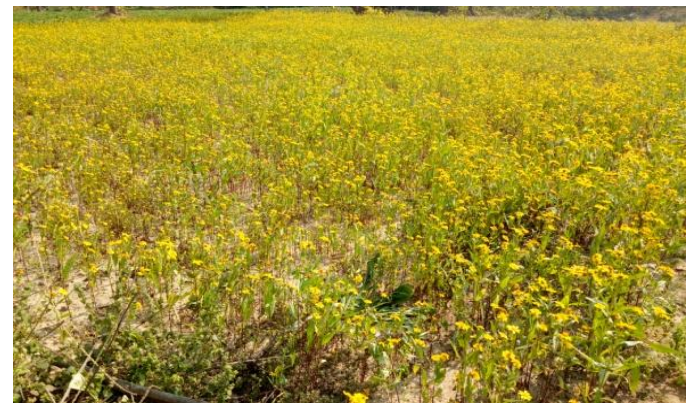

Chavan, S. P., Jadhav, S. N. and More, V. G irrigation schedule on soybean during summer season. Journal of Maharashtra Agriculture Unit. 23 (1): 76-77.

Hafeez Ullah, Gulzar Ahmad and Zar Quresh (2001) Effect of weed control treatments on the performance of sunflower. Online Journal of biological science. 1 (3): 132133.

Calskan, M. E., Gungel, E. Cagar and Mert, M (2002) Effect of sowing dates on phenological development, yield and oil content of sunflower in a Mediterranean type of environment. Indian Journal of Agronomy. 47 (3): 427-432.

Gaurilow, A. M., Zhidkov, V. M., Asthkhov, A. A. and Konovalenko, S. A (2003) Sunflower productivity and seed oil quality depending on sowing time. Russian Agricultural Sciences. 20 (11): 58.

Damavandi, A., Latifi, N. and Mirnejad, M (2005) Study the effect of planting date on growth and development and grain (1998) Effect of dates of sowing and 
yield of two oil sunflower cultivars. Agricultural Science and Technology. 19 (1): 147-158.

Jadhav, A.S. and Deshmukh, L.S (2008) Response of niger (Guizotia abyssinica Cass.) to sowing time and fertility levels. Journal of Oilseeds Research. 25 (2): 212213.

Matinfer, M., Seyfzadeh, S., Shirani rad, A.H. and Baghestani, M.A (2011) Effect of different methods of chemical weed control irrigation regimes on weed biomass and safflower yield. Journal of crop ecophysiology. 5(17): 53-64.

Hegde, D.M (2012) Carrying capacity of Indian agriculture: Oilseeds. Current Science. 102 (06): 867-873.
Jagtap, P.K., Sandipan, P.B. and Patel,M.C (2014) Performance of niger as influenced by various resource constraints. International Journal of current research. 6(8).

Jagtap, P.K. and Manharbhai, C. Patel (2015) Optimization of niger (Guizotia abyssinica Cass.) production under various resource constraints. Journal of global bioscience. Vol. 4.

Madhu Bala and Kedar Nath (2015) Performance of Groundnut as influenced by various resource constraints. International Journal of development Research. 5: 4261- 4263.

\section{How to cite this article:}

Chanchila Kumari, Binit Kumar, Manish Kumar and V.K. Singh. 2018. Evaluating the Impact of Contingent Crop (Niger) on Rice Fellow Upland under Rainfed Ecosystem of Jharkhand. Int.J.Curr.Microbiol.App.Sci. 7(05): 2837-2841. doi: https://doi.org/10.20546/ijcmas.2018.705.329 